\title{
A new species of green pit vipers of the genus Trimeresurus Lacépède, 1804 (Reptilia, Serpentes, Viperidae) from western Arunachal Pradesh, India
}

\author{
Zeeshan A. Mirza ${ }^{1}$, Harshal S. Bhosale ${ }^{2}$, Pushkar U. Phansalkar ${ }^{3}$, Mandar Sawant ${ }^{2}$, \\ Gaurang G. Gowande ${ }^{4,5}$, Harshil Patel ${ }^{6}$ \\ 1 National Centre for Biological Sciences, TIFR, Bangalore, Karnataka 560065, India \\ 2 Bombay Natural History Society, Mumbai, Maharashtra 400001, India \\ 3 A/2, Ajinkyanagari, Karvenagar, Pune, Maharashtra 411052, India \\ 4 Annasaheb Kulkarni Department of Biodiversity, Abasaheb Garware College, Pune, Maharashtra 411004, India \\ 5 Department of Biotechnology, Fergusson College, Pune, Maharashtra 411004, India \\ 6 Department of Biosciences, Veer Narmad South Gujarat University, Surat, Gujarat 395007, India \\ http://zoobank.org/F4D892E1-4D68-4736-B103-F1662B7D344D
}

Corresponding author: Zeeshan A. Mirza (snakeszeeshan@gmail.com)

Academic editor: Peter Bartsch • Received 13 November 2019 • Accepted 9 March 2020 • Published 15 April 2020

\begin{abstract}
A new species of green pit vipers of the genus Trimeresurus Lacépède, 1804 is described from the lowlands of western Arunachal Pradesh state of India. The new species, Trimeresurus salazar, is a member of the subgenus Trimeresurus, a relationship deduced contingent on two mitochondrial genes, $16 S$ and ND4, and recovered as sister to Trimeresurus septentrionalis Kramer, 1977. The new species differs from the latter in bearing an orange to reddish stripe running from the lower border of the eye to the posterior part of the head in males, higher number of pterygoid and dentary teeth, and a short, bilobed hemipenis. Description of the new species and T. arunachalensis Captain, Deepak, Pandit, Bhatt \& Athreya, 2019 from northeastern India in a span of less than one year highlights the need for dedicated surveys to document biodiversity across northeastern India.
\end{abstract}

\section{Key Words}

Biodiversity hotspot, Crotalinae, cryptic species, Himalayas, molecular phylogeny, northeastern India, taxonomy

\section{Introduction}

The pit vipers of the genus Trimeresurus Lacépède, 1804 are charismatic venomous serpents, with morphologically as well as ecologically diverse species (Sanders et al. 2004). They are distributed across east and southeast Asia. At least 48 nominate species (Gumprecht et al. 2004; Whitaker and Captain 2004; Wallach et al. 2014; Captain et al. 2019) are known, of which at least 15 occur in India. Of the species recorded from India, seven species occur in northeastern India (Whitaker and Captain 2004; Captain et al. 2019). The most recent compilations on Indian snakes, listed the following species from northeastern In- dia, namely: T. erythrurus (Cantor, 1839), T. gumprechti David, Vogel, Pauwels \& Vidal, 2002, T. medoensis Zhao, 1977, T. septentrionalis Kramer, 1977, T. albolabris Gray, 1842, T. popeorum Smith, 1937, and T. yunnanensis Schmidt, 1925 (Ao et al. 2004; Gumprecht et al. 2004; Whitaker and Captain 2004; David and Mathew 2005). In addition to the these, a new species, T. arunachalensis Captain, Deepak, Pandit, Bhatt \& Athreya, 2019 was recently described from Arunachal Pradesh. The diversity of pit vipers is likely underestimated, as several species are morphologically cryptic making it difficult to distinguish them in the field (Malhotra and Thorpe 2000, 2004; Zhong et al. 2015; Zhu et al. 2016; Mulcahy et al. 2017). 
For the delimitation of cryptic species, multiple lines of evidence are imperative, including morphology as well asmolecular and ecological data (Sanders et al. 2006; Mirza et al. 2018).

During a herpetological expedition, Arunachal Pradesh was visited between 25 June 2019 and 5 August 2019. Arunachal Pradesh belongs to the Himalayan biodiversity hotspot and shows a high degree of heterogeneity in its landscape with elevation ranging from 100 to $7000 \mathrm{~m}$ and distinct climatic regimes that harbour diverse flora and fauna. Most of the state is part of the undulating terrain of the Himalayas, intersected by numerous rivers, which flow from the Himalayas and form a longitudinal network of parallel flowing rivers, which ultimately meet the River Brahmaputra. The lowland area bordering Assam mostly shares a similar biotope to that of northern Assam. During the expedition, near Pakke Tiger Reserve, we collected two specimens of a green pit viper, which resembled Trimeresurus septentrionalis and Trimeresurus albolabris in the number of dorsal scale rows and colouration. However, these specimens differed in the colouration of the lateral stripe on the head and the body in males. Comparison of the specimens from near Pakke Tiger Reserve with $T$. septentrionalis and $T$. albolabris (specimens examined $=$ 11) housed in the collection of the Bombay Natural History Society (Mumbai, India), Natural History Museum (London, UK), and the data presented in the literature (Smith 1943; Gumprecht et al. 2004) revealed that the specimens from near Pakke Tiger Reserve represent a new species. Molecular data for the specimens corroborate our morphological findings and allow us to describe a new species of green pit vipers from northeastern India.

\section{Material and methods}

\section{Morphology}

The study was conducted under permit no. CWL/ Gen/173/2018-19/Pt.V11/2421-33 and CWL/ Gen/173/2018-19/Pt.V11/2434-43 issued by the Forest Department of Arunachal Pradesh. Two specimens of the new species were collected by hand in the field, photographed, and later euthanized with halothane within $24 \mathrm{~h}$ of capture following ethical guidelines for animal euthanasia (Leary et al. 2013). The specimens were fixed in $8 \%$ formaldehyde buffer and later stored in $70 \%$ ethanol. Liver tissue was collected for molecular work and stored in molecular grade ethanol prior to specimen fixation. The specimens have been deposited in the collection of the Bombay Natural History Society (BNHS), Mumbai. Measurements were taken with the help of digital callipers to the nearest $0.1 \mathrm{~mm}$ and those for snout to vent length (SVL) and tail length (TaL) were taken with a string, which was then measured using a scale. Ventral scales (V) were counted as directed by Dowling (1951). Dorsal scales at midbody were counted at midway of the SVL. Cephalic scales (CEP) number was counted on a straight line between the middle of the supraoculars; longitudinal cephalic scales (LCS) number of scales counted from the posterior border off the internasals to the neck (which is here defined as the dorsal scale row, which corresponds to the first ventral scale). Abbreviations used in the description: $\mathrm{TL}=$ total length, $\mathrm{HL}=$ head length measured from snout tip to the angle of the jaw, VED = vertical extent of the eye, DEYE = diameter of the eye measured between edges of scales surrounding it, DEL $=$ distance between lower eye margin and the edge of lip. Morphological data for the new species were compared with the types of the sister taxa based on molecular data and original descriptions of sister species were referred to, too. Morphological data from literature were largely derived from Gumprecht et al. (2004), Kramer (1977) and Regenass and Kramer (1981).

Micro-CT scan were generated for the male holotype using a Bruker Skyscan 1272 (Bruker BioSpin Corporation, Billerica, Massachusetts, USA). Head of the specimen was scanned for 210 minutes at resolution of $5.4 \mu \mathrm{m}$ and recording data for every $0.4^{\circ}$ rotation for $360^{\circ}$ with (AL) $1 \mathrm{~mm}$ filter. The source voltage for the scan was $65 \mathrm{kV}$ and source current was $153 \mathrm{uA}$. Volume rendering was performed with CTVox (Bruker BioSpin Corporation, Billerica, Massachusetts, USA) and images were edited in Adobe Photoshop CS6. Osteological description is based on volume renders retrieved from CTVox following terminology of the skull described by Heatwole (2009).

\section{Institution acronyms}

BNHS Bombay Natural History Society, Mumbai, India; MNHN Muséum national d'Histoire naturelle, Paris, France;

NCBS Collection Facility of the National Centre for Biological Sciences, Bangalore, India;

NHM Natural History Museum, London, UK;

ZMUC Zoological Museum University of Copenhagen, Denmark.

Comparative material examined:

Trimeresurus albolabris NHM 1946.1.19.85, lectoype, China; BNHS 2652-2653, Taungyi Myanmar; BNHS 2654, Mayniyo, Myanmar; BNHS 2655, Myanmar; BNHS 2656, Bangkok, Thailand; BNHS 2659, Moulinein, Myanmar; BNHS 3304, Car Nicobar, India;

Trimeresurus erythrurus NCBS-AG767, NCBSAG776, NCBS-AG781-782, Tripura, India

Trimeresurus gumprechti MNHN 1999.9072 holotype \& MNHN 1999.9073 paratype, Loei, Loei Province, Thailand, paratype;

Trimeresurus popeiorum NHM 1872.4.17.137, lectotype, Khasi hills, Meghalaya, India; BNHS 2638-2640, Tindharia, Darjeeling, West Bengal, India; BNHS 2637, Tura, Garo Hills, Meghalaya; 
Trimeresurus septentrionalis NHM 1937.3.1.15 paratype, Kullu District, Himachal Pradesh, India; paratype NHM 1937.3.1.15, paratype NHM 1955.1.13.82;

Trimeresurus yunnanensis BNHS 2634, Shillong, Meghalaya; BNHS 2635, Tura, Assam; BNHS 2636, Tindharia, Darjeeling, West Bengal, India.

\section{Molecular analysis}

Genomic DNA was isolated from the preserved tissues of the type specimens using QIAGEN DNeasy kits following protocols directed by the manufacturer. Molecular methods largely follow Mirza et al. (2016) and Mirza and Patel (2018). A fragment of the mitochondrial 16S rRNA $(16 S)$ and NADH-ubiquinone oxidoreductase, subunit 4 (ND4) gene were amplified using primers used by Pyron et al. (2013) and Mirza et al. (2016). A $22.4 \mu$ reaction was set for a bi-directional Polymerase Chain Reaction (PCR), containing $10 \mu \mathrm{l}$ of Thermo Scientific DreamTaq PCR Master Mix, $10 \mu \mathrm{l}$ of molecular grade water, $0.2 \mu \mathrm{l}$ of each $10 \mu \mathrm{M}$ primer and $2 \mu \mathrm{l}$ template DNA, carried out with an Applied Biosystems ProFlex PCR System. Thermo-cycle profile used for amplification were as follows: $95{ }^{\circ} \mathrm{C}$ for $3 \mathrm{~min}$, (denaturation temperature $95{ }^{\circ} \mathrm{C}$ for $30 \mathrm{sec}$, annealing temperature $60{ }^{\circ} \mathrm{C}$ for $N D 4$, and $45{ }^{\circ} \mathrm{C}$ for $16 \mathrm{~S}$ for $45 \mathrm{sec}$, elongation temperature $72{ }^{\circ} \mathrm{C}$ for 1 minutes) $\times 36$ cycles, $72{ }^{\circ} \mathrm{C}$ for $10 \mathrm{~min}$, hold at $4{ }^{\circ} \mathrm{C}$. PCR product was cleaned using QIAquick PCR Purification Kit and sequenced with an Applied Biosystems 3730 DNA Analyzer. In addition to this, $16 S$ and ND4 sequences of Trimeresurus spp. available on GenBank were downloaded for molecular phylogenetic reconstructions (Appendix I), and the sequences were concatenated using SequenceMatrix. Taxa for molecular phylogenetics were selected based on the tree topologies recovered by Figueroa et al. (2016). Sequences were aligned in MegaX (Kumar et al. 2018) using ClustalW (Thompson and Gibson 2002) with default settings. For optimal partitioning strategy and evolutionary substitution model, aligned data was analyzed using PartitionFinder v. 1.1.1. (Lanfear et al. 2012), implementing a greedy search algorithm under the Akaike Information Criterion (AIC). Dataset was partitioned as per-codon position for the ND4 gene, whereas the $16 S$ region was not partitioned per-codon position. Maximum Likelihood (ML) analysis was carried out using raxmlGUI (Silvestro and Michalak 2012), 1000 non-parametric bootstrap pseudo-replicates were performed with rapid ML search option. Bayesian Inference (BI) was implemented in MrBayes 3.2.2. (Ronquist and Huelsenbeck 2003) and was run for 10 million generations and sampled every 1000 generations. BI run included five parallel chains, three hot and tow cold chains. The standard deviation of split frequencies of the analysis reached were below 0.01 , after which the analysis was not continued further. Twenty-five percent of trees generated were discarded as burn-in. Data were subjected to phylogenetic reconstructions with generalised time-reversible (GTR) model as the sequence substitution model, based on the optimal partitioning scheme suggested by PartitionFinder for both ML and BI. Uncorrected pairwise $p$-distance $(\%$ sequence divergence) was calculated in MegaX (Kumar et al. 2018) with pairwise deletions of missing data and gaps. Details of sequences and GenBank accession numbers are presented in supporting files (Appendix I).

\section{Results}

Trimeresurus salazar sp. nov.

http://zoobank.org/6C165D3E-D3F2-43CA-A62E-E753E6B7FC22 Figs $1-5,7$

Holotype. BNHS 3554, adult male, collected from outskirts of Pakke Tiger Reserve, 0.64 nautical miles $(1.19 \mathrm{~km})$ north of Seijosa, East Kameng district, Arunachal Pradesh (26.968790N, 93.013984E, elevation $172 \mathrm{~m}$ a.s.1, datum WGS84), India by Harshal Bhosale, Pushkar Phansalkar, Mandar Sawant, and Zeeshan Mirza on 1 July 2019

Paratype. BNHS 3555, adult female same data as for the holotype but collected on 5 July 2019.

Referred material. ZMUC R69255 \& ZMUC R69256, males, from Assam, India purchased by B.W. Westermann.

Etymology. The specific epithet is a noun in apposition for J.K. Rowling's fictional Hogwarts School of Witchcraft and Wizardry's co-founder, Salazar Slytherin. He was a Parselmouth that links him to serpents. Suggested common name: Salazar's pit viper.

Diagnosis. A species of the genus Trimeresurus with (1) $1^{\text {st }}$ supralabial fused with nasal; (2) 19-21 moderately keeled dorsal scale rows at midbody; (3) dorsal colouration greenish yellow in both sexes; (4) an orange to reddish stripe extends from the posterior borders of the preocular, running through the lower margin of the eyes to the lateral side of the nape in males; (5) ventrolateral stripe predominantly yellow with a faint orange at the base in males, yellow in females; (6) tail to total length ratio (TaL/TL) 0.18 in males, 0.14 in females; (7) short, bilobed hemipenis reaching $8^{\text {th }}$ caudal scale; (8) 6 palatine, 15 pterygoid and 19 dentary teeth.

Comparison. The new species is here compared to all species of the genus Trimeresurus for differing and non-overlapping characters: first supralabial fused with nasal (vs separate in T. macrolepis Beddome, 1862, T. trigonocephalus (Latreille, 1801), T. malabaricus (Jerdon, 1854), T. strigatus Gray, 1842, T. gramineus (Shaw, 1802), T. stejnegeri Schmidt, 1925, T. hageni (Lidth de Jeude, 1886), T. phuketensis Sumontha, Kunya, Pauwels, Nitikul \& Punnadee, 2011, T. nebularis Vogel, David \& Pawels, 2004, T. truongsonensis Orlov, 
Ryabov, Thanh \& H. Cuc, 2004, T. gunaleni Vogel, David \& Sidik, 2014, T. sabahi Regenass \& Kramer, 1981, T. popeorum, T. yingjiangensis Chen, Zhang, Shi, Tang, Guo, Song \& Ding, 2019, T. sichuanensis (Guo \& Wang, 2011), T. nebularis Vogel, David \& Pauwels, 2004, and T. yunnanensis); dorsal scale rows 19-21 (vs $>23$ rows in T. andersoni Theobald, 1868, T. cantori (Blyth, 1846), T. erythrurus, T. gracilis Oshima, 1920, T. gumprechti, T. labialis (Steindachner, 1867), T. purpureomaculatus (Gray, 1832), T. vogeli David, Vidal \& Pawels, 2001, T. stejnegeri, and T. arunachalensis); eye sized in relation to head not large, DEYE 2.33 (DEYE 4.03-4.46 relatively large eyes in T. cardomomensis Malhotra, Thrope, Mrinalini \& Staurt, 2011, T. macrops Karmer, 1977, and T. rubeus Malhotra, Thrope, Mrinalini \& Staurt, 2011), dorsum green with a yellow tinge bearing a yellowish ventrolateral stripe along the body lacking any dorsal markings (vs dorsum reddish brown to grey, black, or green with dark markings in T. tibetanus Huang, 1982, T. flavomaculatus (Gray, 1842), T. fasciatus (Boulenger, 1896), T. arunachalensis, T. malabaricus, T. strigatus, T. kanburiensis Smith, 1943, T. puniceus (Boie, 1827), T. schultzei Griffin, 1909, T. mutabilis Stoliczka, 1870, T. honsonensis (Grismer, Ngo \& Grismer, 2008), T. malcolmi Loveridge, 1938, T. wiroti Trutnau, 1981, T. venustus, Vogel, 1991, T. mcgregori Taylor, 1919, T. sumatranus (Raffles, 1822), T. andersonii, T. labialis, $T$. andalasensis David, Vogel, Vijaykumar \& Vidal, 2006, T. borneensis (Peters, 1872), T. brongersmai Hoge, 1968, T. cantori); 167-171 ventrals (vs 136-150 in $T$. brongersmai, 141-149 in T. gracilis, 133-143 in T. macrolepis, 143-158 in T. malabaricus, 138-149 in T. medoensis, and 128-150 in T. strigatus).

The new species is most similar to T. septentrionalis, T. insularis Kramer, 1977, and T. albolabris in its scalation but differs in bearing an orange to reddish stripe from the lower margin of the eye to the posterior of the posterior border of the mouth in males (vs a white stripe from the posterior border of the nasal to posterior part of the head in T. septentrionalis and T. albolabris); hemipenis short and bilobed (vs long and deeply forked in $T$. septentrionalis and T. albolabris); palatine with six teeth (vs five in T. albolabris, T. insularis, and T. septentrionalis); pterygoid with 15 teeth (vs 11 in T. septentrionalis, 16 in T. insularis, and 12 in T. albolabris); 19 dentary teeth (vs 11 in T. septentrionalis, 12 in T. albolabris, and 14 in T. insularis). A comparison of selected characters is presented in Table 1.

Description of holotype male BNHS 3554. The specimen is in a good state of preservation, set in a coil with its head placed out of the coil (Fig. 1a). The left hemipenis is everted, and the specimen bears three ventral longitudinal incisions (Fig. 1b). The skin of the specimen seems a bit loose, likely an artifact of preservation.

Body long and thin, SVL $415 \mathrm{~mm}$; head triangular and elongate, head length $16.2 \mathrm{~mm}$ (HL/SVL 0.04); head width $12.6 \mathrm{~mm}$; (HW/HL 0.77) clearly distinct from neck; distance between nostrils $3.2 \mathrm{~mm}$; distance between preoculars $6 \mathrm{~mm}$; distance between tip of snout and anterior border of eye $6.6 \mathrm{~mm}$; distance between nostril to eye $4.8 \mathrm{~mm}$. Canthus rostralis distinct; four scales between internasal and supraocular. Rostral subtriangular, slightly visible when viewed from above; nasal and first supralabial fused, with only a trace of a suture, sub-pentagonal, wider than high $(2.7 \mathrm{~mm}$ high, $3.2 \mathrm{~mm}$ wide); a pair of subrectangular internasals aligned in a straight manner bordered by six scales on its posterior margin; second supralabial and two preoculars encompass the loreal pit; the lower preocular forms the lower margin of the loreal pit (Fig. 2a, b); one elongate and narrow supraocular ( $0.8 \mathrm{~mm}$ wide, 3.9 $\mathrm{mm}$ long); cephalic scales (CEP) small, much irregular, subimbricate, smooth; LCS 35, more elongate near the neck; 12 CEP between supraoculars (Fig. 2d); occipital scales smooth; four to five rows of scales between the internasals and anterior border of the supraoculars flat and irregular in their shape; the rows posterior to these have a slight dome shaped appearance; temporals smooth and subequal; subocular crescent shaped; 11/11 supralabials; $1^{\text {st }}$ supralabial fused with nasal scale, $2^{\text {nd }}$ as high as the $1^{\text {st }}$ supralabial, nearly of the same width throughout; $3^{\text {rd }}$ supralabial longest among the supralabials, lower preocular, subocular and $4^{\text {th }}$ supralabial; $4^{\text {th }}$ supralabial small, separated from the subocular by a single row of smooth scales; $5^{\text {th }}$ supralabial in contact with temporal; the remaining supralabials slightly decreasing in size posteriorly and in contact with temporal scales; $12 / 13$ infralabials, the first pair in contact with each other; the first three pairs in contact with anterior

Table 1. Summary of selected characters for members of the clade containing T. albolabris.

\begin{tabular}{|c|c|c|c|c|c|c|c|}
\hline Species & Dorsal colouration & $\begin{array}{l}\text { Colour of lateral } \\
\text { stripe on head }\end{array}$ & $\begin{array}{c}\text { Dorsal scale } \\
\text { rows at midbody }\end{array}$ & $\mathrm{TaL} / \mathrm{TL}$ & Ventrals & Subcaudals & Hemipenis \\
\hline T. albolabris & Green & White & 21 & $0.19-0.24$ & $149-173$ & $48-67$ & bilobed, long \\
\hline T. andersonii & Brown or black & - & 23 or 25 & 0.16 & $171-183$ & $53-74$ & bilobed, long \\
\hline T. cantori & Green or brown & White & 27 or 31 & $0.12-0.20$ & $170-176$ & $44-73$ & bilobed, long \\
\hline T. erythrurus & Green & White & 23 & $0.16 / 0.21$ & $151-174$ & $49-67$ & bilobed, long \\
\hline T. fasciatus & Brown & - & 21 & $0.18-0.21$ & $158-163$ & $63-65$ & bilobed, long \\
\hline T. insularis & Green or blue & - & 21 & $0.21-0.22$ & $156-167$ & $54-75$ & bilobed, long \\
\hline T. purpureomaculatus & Black to dark brown & - & 23 to 27 & $0.16-0.19$ & $152-183$ & $54-79$ & bilobed, long \\
\hline T. septentrionalis & Green & White & 21 & $0.19-0.24$ & $160-181$ & $55-83$ & bilobed, long \\
\hline T. salazar sp. nov. & Green & Reddish orange & 19 or 21 & $0.14-0.18$ & $163-171$ & $59-74$ & $\begin{array}{l}\text { bilobed, } \\
\text { short }\end{array}$ \\
\hline
\end{tabular}



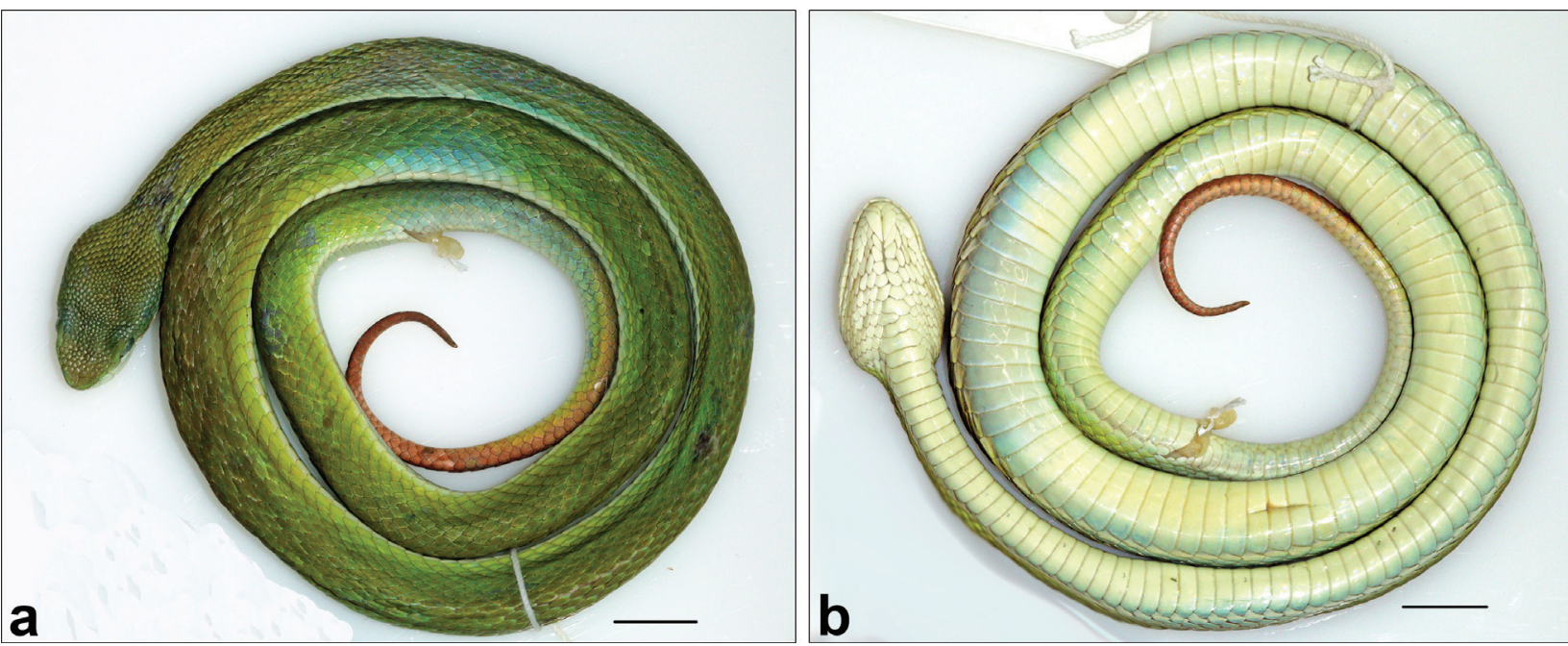

Figure 1. Trimeresurus salazar sp. nov. holotype male BNHS 3554. a. Dorsal aspect; b. Ventral aspect. Scale bar: $10 \mathrm{~mm}$.
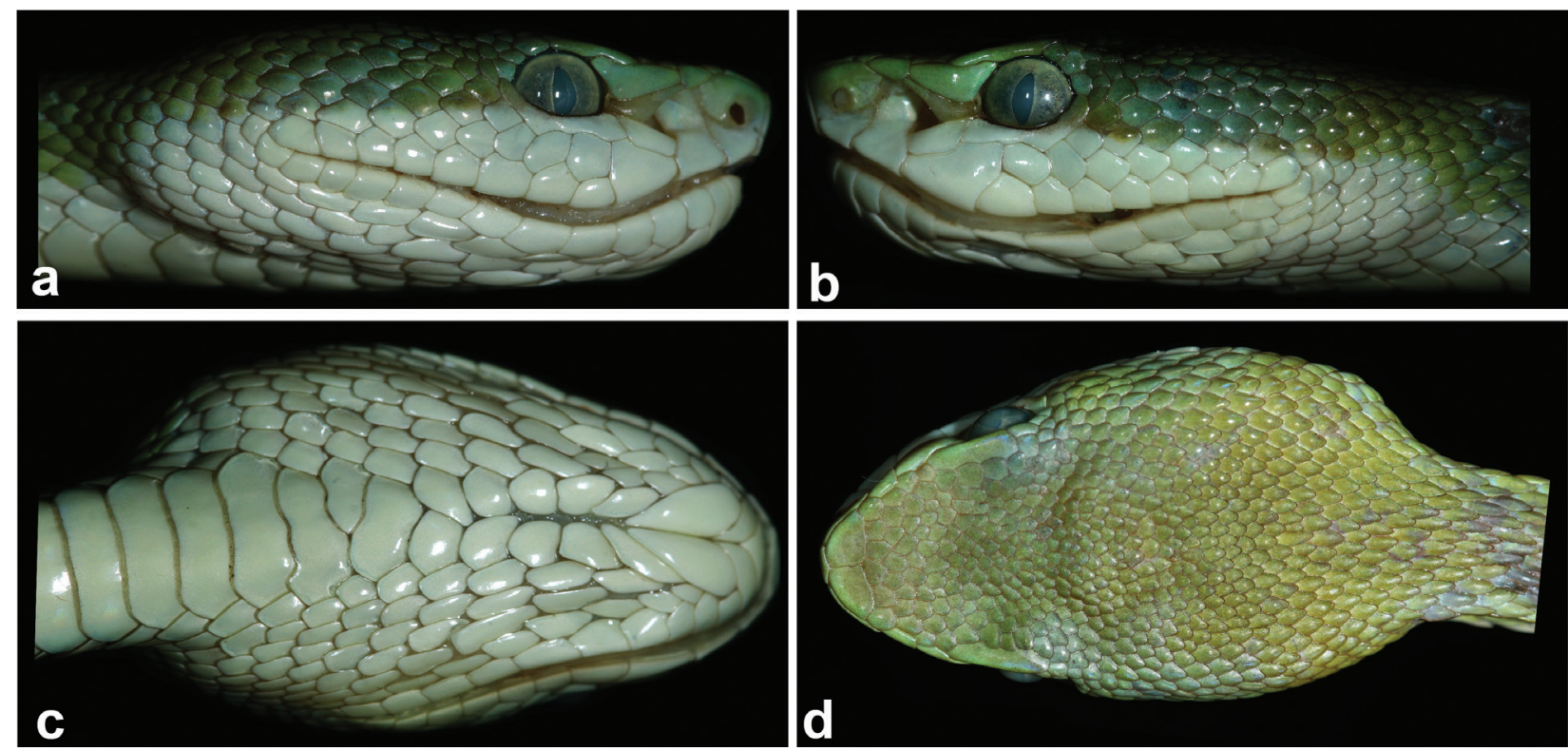

Figure 2. Trimeresurus salazar sp. nov. holotype male BNHS 3554. A. Right view of head; b. Left view of head; c. Ventral view of head; $\mathbf{d}$. Dorsal view of head. Not to scale.

chin shields; six pairs of chin shields, each pair in contact medially; separated from infalabials by $1-5$ scale rows (Fig. 2c). Palatine with six teeth; pterygoid with 15 teeth; 19 dentary teeth (Fig. 4).

Body scalation: 21 dorsal scales one head length behind the head; 19 dorsal scales at midbody; 15 dorsal scales one head length anterior to the vent; dorsal scales rhomboid, moderately keeled except for the first row which is smooth; three preventrals; 167 ventral scales; 71 subcaudal scales; paired; anal shield entire. Eye large, with VED/ DEL ratio 0.85; tail short; ventrally depressed; Tal $94 \mathrm{~mm}$; TaL/TL 0.18. Tail prehensile. Hemipenis short, bilobed, not deeply forked, extending to the $8^{\text {th }}$ caudal scale.

Colouration in life (Figs 5a, b, 7): dorsum green with a yellow tinge; ventrum creamy white with the dorsal green colour diffusing into the ventral scales on the ventral scale margins. Head dorsally dark green, which fades to lighter green to yellowish green on the nasal, labials, and preoculars. A reddish orange stripe extends from the posterior borders of the preoculars, running through the lower margin of the eyes to the lateral side of the nape. Dorsal scales yellowish green except for the first dorsal scale row, which is yellowish white and bears a faint orange patch; the yellow and the orange appears as a bicoloured lateral stripe running form the neck to the vent. Tail rusty red dorsally and orange ventrally. Juveniles are brightly coloured, and the lateral stripe on the head is more prominent (Fig. 7).

Colouration in preservative (Figs 1a, b, 2a-c): green on dorsum has turned darker and the yellow has faded to white. In some patches, the green has turned light blue. The orange stripe along the head and along the body is not visible. The tail is reddish brown and has lost all trace of the orange tinge. 

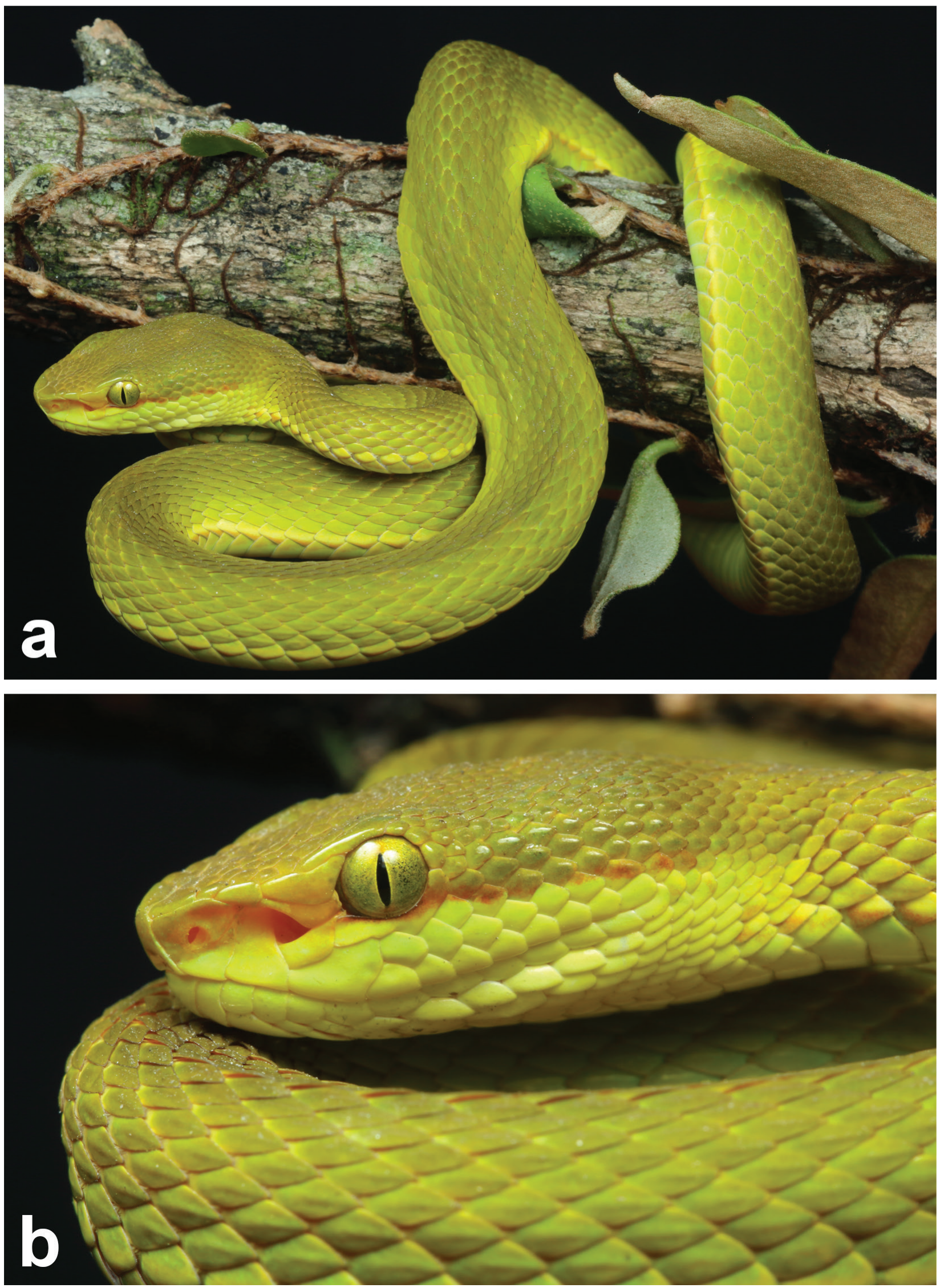

Figure 3. Trimeresurus salazar sp. nov. holotype male BNHS 3554 in life. a. Body habitus; b. Left lateral view of head. 

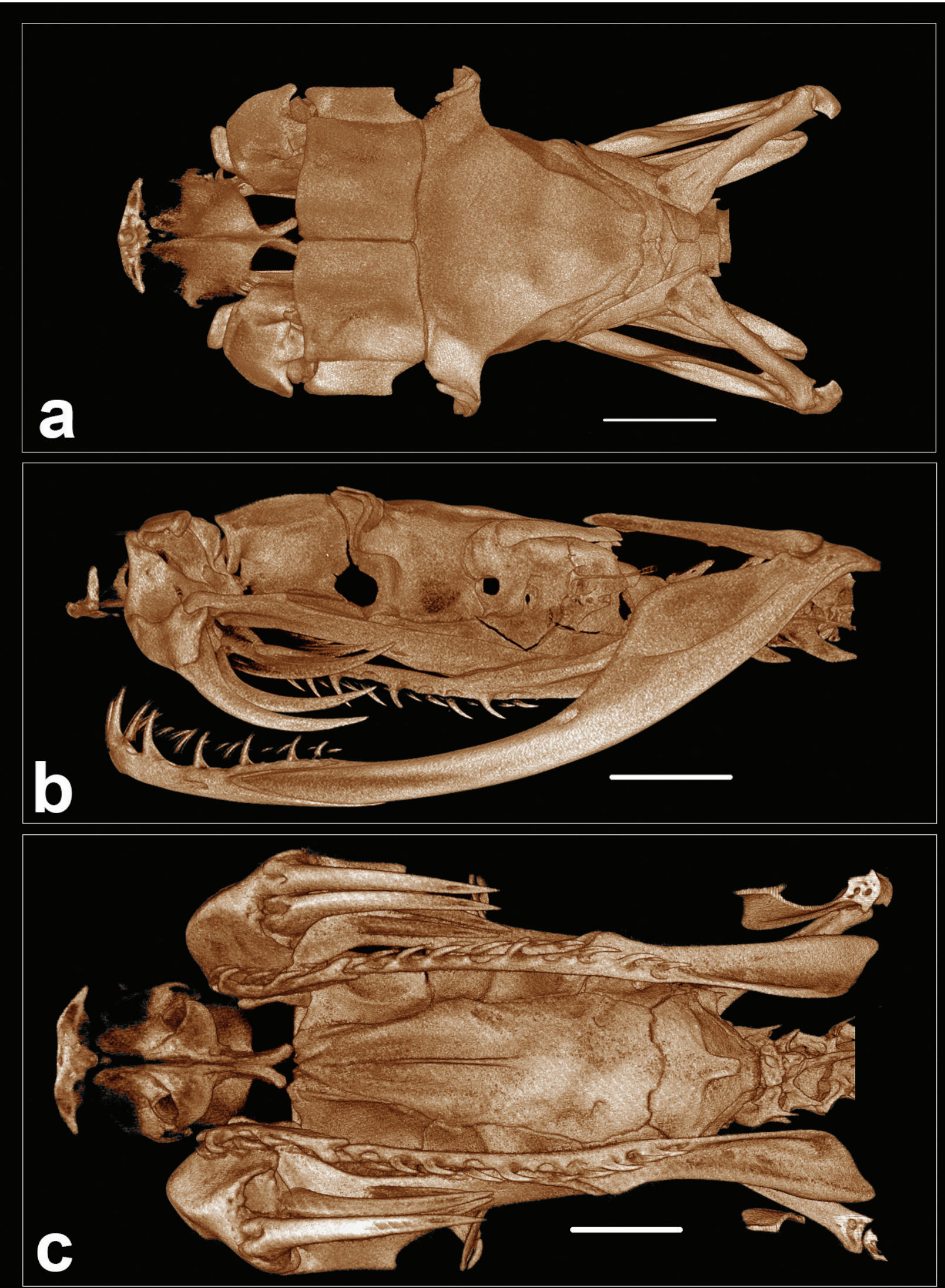

Figure 4. Micro-CT volume rendered images of the skull and mandibles of the holotype male BNHS 3554. a. Dorsal view; b. Left lateral view; c. Ventral view (lower jaw clipped for representation purpose). Scale bars: $2.5 \mathrm{~mm}(\mathbf{a}, \mathbf{b}) ; 2 \mathrm{~mm}(\mathbf{c})$. 

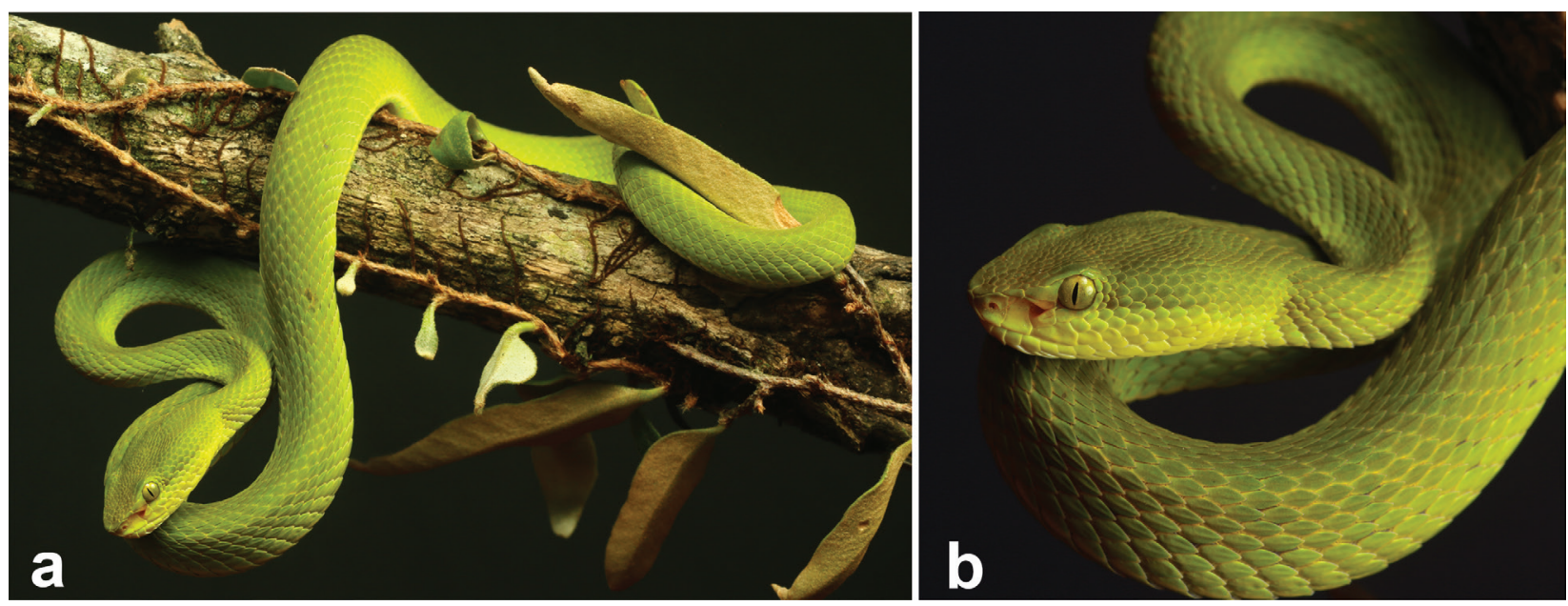

Figure 5. Trimeresurus salazar sp. nov. paratype female BNHS 3555 in life. a. Body habitus; b. Left lateral view of head.

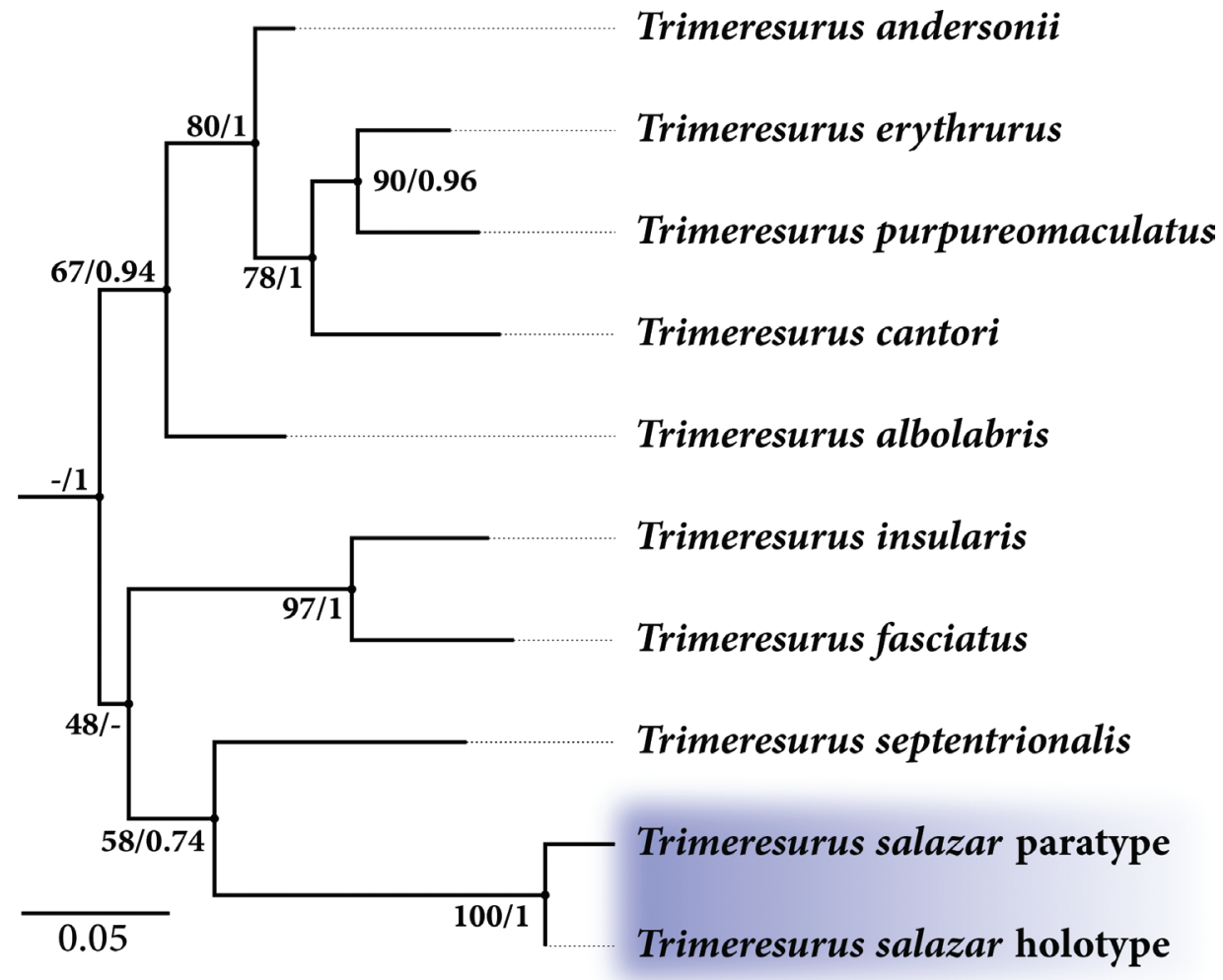

Figure 6. ML phylogeny of selected members of the subgenus Trimeresurus based on partial sequences of mitochondrial $16 S$ and ND4 gene generated through 1000 non-parametric bootstrap pseudoreplicates under the GTR $+\mathrm{G}$ model of sequence evolution. Numbers at nodes represent ML bootstrap support and BI posterior probabality. See Appendix III for a complete tree.

Variation: the paratype female BNHS 3555 agrees with the description of the holotype in most aspects except for the following difference: 21 dorsal scales rows at one head length posterior to head and at midbody; 15 dorsal scale rows one head length anterior to vent; $10 \mathrm{CEP}$; 32 scales in a longitudinal row from internasals to neck; 10/10 supralabials; $13 / 12$ infralabials; 171 ventral scales (+3 preventral scales); 59 paired subcaudal scales; SVL $363 \mathrm{~mm}$; TaL $60 \mathrm{~mm}$; TaL/TL 0.14 . The species is sexually dichromatic; the male bears a reddish orange stripe running from the margin of the eye and subocular through the temporal region, and from the neck to the vent as a lateral stripe, which the female lacks (Fig. 5a, b). See Appendix III for images of the paratype. Two male specimens from Assam, ZMUC R69255 bore ventrals 164 (+2 preventrals) and 74 subcaudals, and ZMUC R69256 ventrals 163 (+2 preventrals) and 71 paired subcaudals.

Natural history notes: the type specimens were found during night search between 1800-2200 hours along a road. Both individuals were found coiled on shrubs along the road. A third individual was seen but escaped in the thick undergrowth. Three individuals were seen during 


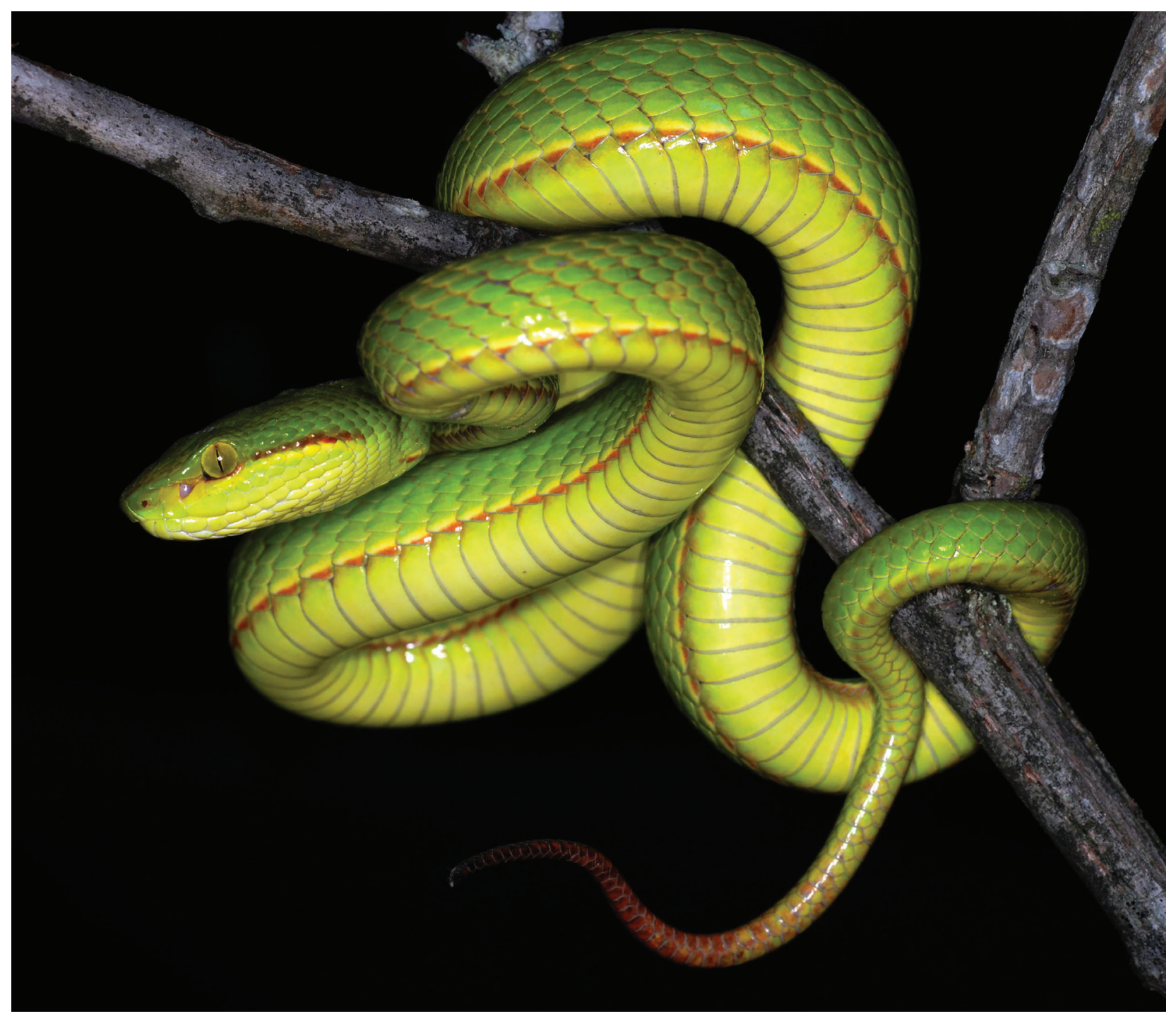

Figure 7. Trimeresurus salazar sp. nov. juvenile male from Pakke Tiger Reserve photographed in 2008. Photo by Aamod Zambre and Chintan Seth, Eaglenest Biodiversity Project.

night searches in six nights. Other serpent species observed at the locality include Boiga gokool (Gray, 1834), Boiga cyanea (Duméril, Bibron \& Duméril, 1854), and Lycodon jara (Shaw, 1802). For now, the new species is known only from the type locality. The specimens, ZMUC R69255 \& ZMUC R69256 were collected from Assam and it is likely that the new species may occur in the adjoining state sharing similar biotope.

\section{Discussion}

Phylogenetic relationships within the genus Trimeresurus are resolved, and the studies by Malhotra and Thorpe $(2000,2004)$ and Giannasi et al. (2001) have demonstrated presence of distinct clades which have been assigned subgeneric status. David et al. (2011) suggested valuable amendments in the nomenclature of the generic splitting, and in following them, we thus assign the new species to the subgenus Trimeresurus Lacépède, 1804. There is a broad gap in our knowledge of the species diversity in India, especially in northeastern India, as we lack molecular data for samples across the northeastern Indian states. However, based on a short fragment of $16 \mathrm{~S}$ and ND4 gene, the new species was recovered as sister to T. septentrionalis (Fig. 6), with moderate support (ML bootstrap 58 and BI posterior probability 0.74 ), from which it differs by an uncorrected pairwise sequence divergence ( $p$-distance) of $6 \%$ on ND4 (Appendix II). Furthermore, the new species is recorded from an elevation of $172 \mathrm{~m}$ a.s.l. and is distributed in the eastern parts of the Himalayan range, whereas T. septentrionalis is distributed between above 700-3050 m a.s.l. from central Nepal to Himachal Pradesh in the Western Himalayas (Kramer 1977; Regenass and Kramer 1981; Whitaker and Captain 2004; Sharma et al. 2013).

This is the second species of snake discovered after Trachischium apteii Bhosale, Gowande \& Mirza, 2019 (Bhosale et al. 2019) from the Arunachal Pradesh expedition 
led by the authors, which merely reflects the poor nature of biodiversity documentation across northeastern India. Future dedicated surveys conducted across northeastern India will help document biodiversity, which is under threat from numerous development activities that include road widening, agriculture, and hydro-electric projects.

\section{Acknowledgements}

We thank the Forest Department of Arunachal Pradesh for issuing the necessary permits (permit no. CWL/ Gen/173/2018-19/Pt.V11/2421-33 to GG and CWL/ Gen/173/2018-19/Pt.V11/2434-43 to ZM) to conduct surveys across the state. Singinawa Conservation Foundation supported ZAM. HB and his team extend their most heartfelt gratitude to Shripad Halbe and Brihad Bharatiya Samaj for their generous support in funding the expedition. We also thank Sandesh Kadur, Buban Gogoi and Debabrata Phukon for his help with the logistics, and Deepak Apte and Rahul Khot BNHS for their constant support. GG was partially supported by the Rufford Small Grants for Nature Conservation. ZAM acknowledges support from the NCBS Infosys Travel Grant to visit the NHM, MNHN, and ZMUC. GG is indebted to the Principal, Abasaheb Garware College, to the HoD, Annasaheb Kulkarni Department of Biodiversity, Abasaheb Garware College, and to the Principal, Fergusson College, and to the HoD, Biotechnology, Fergusson College and his advisor Dhanashree Paranjpe, for their constant support and encouragement. ZM thanks K. VijayRaghavan for guidance and to all lab mates for their support. Visit to museums would not have been possible without the help of an Infosys Travel Grant. Special thanks go to Sunil P. (NCBS EM facility) for help with CT scan and data analysis, which benefitted the manuscript greatly and the NCBS sequencing facility. We thank Aamod Zambre for sharing and allowing us to use the image of the juvenile from Pakke Tiger Reserve. ZM acknowledges Nicolas Vidal (MNHN), Patrick Campbell (NHM), and Peter Møller (ZMUC) for providing access to the museum collections. The manuscript greatly benefitted from constructive comments by the reviewer.

\section{References}

Ao J, David P, Bordoloi S, Ohler A (2004) Notes on a collection of snakes from Nagaland, northeast India, with 19 new records for this state. Russian Journal of Herpetology 11: 155-162.

Bhosale HS, Gowande G, Mirza ZA (2019) A new species of fossorial natricid snakes of the genus Trachischium Günther, 1858 (Serpentes: Natricidae) from the Himalayas of northeast India. Comptes Rendus Biologies 342: 323-329. https://doi.org/10.1016/j.crvi.2019.10.003

Captain A, Deepak V, Pandit R, Bhatt B, Athreya R (2019) A new species of pitviper (Serpentes: Viperidae: Trimeresurus lacepède, 1804) from west Kameng District, Arunachal Pradesh, India. Russian Journal of Herpetology 26: 111-122. https://doi.org/10.30906/10262296-2019-26-2-111-122
David P, Mathew R (2005) Notes on some noteworthy snake specimens deposited in the collections of Eastern Regional Station of the Zoological Survey of India. Records of Zoological Survey of India. Occasional Papaer 104: 83-90.

David P, Vogel G, Dubois A (2011) On the need to follow rigorously the rules of the code for the subsequent designation of a nucleospecies (type species) for a nominal genus which lacked one: the case of the nominal genus Trimeresurus Lacépède, 1804 (Reptilia: Squamata: Viperidae). Zootaxa 51: 1-51.

Dowling H (1951) A proposed standard system of counting ventrals in snakes. British Journal of Herpetology 11: 97-99.

Figueroa A, Mckelvy AD, Grismer LL, Bell CD (2016) A species-level phylogeny of extant snakes with description of a new colubrid subfamily and genus. PLoS ONE 11: e0161070. https://doi.org/10.1371/ journal.pone. 0161070

Giannasi N, Thorpe RS, Malhotra A (2001) The use of amplified fragment length polymorphism in determining species trees at fine taxonomic levels: analysis of a medically important snake, Trimeresurus albolabris. Molecular Ecology 10: 419-426. https://doi. org/10.1046/j.1365-294X.2001.01220.x

Gumprecht A, Tillack F, Orlov NL, Captain A, Raybov S (2004) Asian pitvipers. GeitjeBooks Berlin, Berlin, 368 pp.

Heatwole H (2009) Biology of the Reptilia. Volume 20, morphology $\mathrm{H}$, the skull of Lepidosauria. In: Gans C, Gaunt AS, Adler K (Eds) Society for the Study of Amphibians and Reptiles, Ithaca, 610-611. https://doi.org/10.1093/icb/icp063

Kramer E (1977) Zur Schlangenfauna Nepals. Revue suisse de Zoologie 84: 721-761. https://doi.org/10.5962/bhl.part.91420

Kumar S, Stecher G, Li M, Knyaz C, Tamura K (2018) MEGA X: Molecular Evolutionary Genetics Analysis across computing platforms. Molecular Biology and Evolution 35: 1547-1549. https://doi. org/10.1093/molbev/mst197

Lanfear R, Calcott B, Ho S, Guindon S (2012) PartitionFinder: combined selection of partitioning schemes and substitution models for phylogenetic analyses. Molecular Biology and Evolution 29: 16951701. https://doi.org/10.1093/molbev/mss020

Leary S, Underwood W, Anthony R, Cartner S (2013) AVMA guidelines for the euthanasia of animals: 2013 edition. Schaumburg, IL: American Veterinary Medical Association, 98 pp.

Malhotra A, Thorpe RS (2000) A phylogeny of the Trimeresurus group of pit vipers: new evidence from a mitochondrial gene tree. Molecular Marine Biology and Biotechnology 16: 199-211. https://doi. org/10.1006/mpev.2000.0779

Malhotra A, Thorpe RS (2004) A phylogeny of four mitochondrial gene regions suggests a revised taxonomy for Asian pitvipers (Trimeresurus and Ovophis). Molecular Phylogenetics and Evolution 32: 83-100. https://doi.org/10.1016/j.ympev.2004.02.008

Mirza ZA, Gowande G, Patil R, Ambekar M, Patel H (2018) First appearance deceives many: disentangling the Hemidactylus triedrus species complex using an integrated approach. PeerJ: 6:e5341. https://doi.org/10.7717/peerj.5341

Mirza ZA, Patel H (2018) Back from the dead! Resurrection and revalidation of the Indian endemic snake genus Wallophis Werner, 1929 (Squamata: Colubridae) insights from molecular data. Mitochondrial DNA Part A: DNA Mapping, Sequencing, and Analysis 29: 331-334. https://doi.org/10.1080/24701394.2016.1278536

Mirza ZA, Vyas R, Patel H, Maheta J, Sanap RV (2016) A new Miocene-divergent lineage of Old World racer snake from India. 
PloS ONE 11 (3): e0148380. https://doi.org/10.1371/journal. pone. 0148380

Mulcahy DG, Lee JL, Miller AH, Zug GR (2017) Troublesome trimes: potential cryptic speciation of the Trimeresurus (Popeia) popeiorum complex (Serpentes: Crotalidae) around the isthmus of Kra (Myanmar and Thailand). Zootaxa 4347: 301-315. https://doi. org/10.11646/zootaxa.4347.2.6

Pyron RA, Kandambi HKD, Hendry CR, Pushpamal V, Burbrink FT, Somaweera R (2013) Genus-level phylogeny of snakes reveals the origins of species richness in Sri Lanka. Molecular phylogenetics and Evolution 66: 969-978. https://doi.org/10.1016/j.ympev.2012.12.004

Regenass U, Kramer E (1981) Zur Systematik der grünen Grubenottern der Gattung Trimeresurus (Serpentes, Crotalidae). Revue Suisse de Zoologie 88: 163-205. https://doi.org/10.5962/bhl.part.82363

Ronquist F, Huelsenbeck J (2003) MrBayes 3: Bayesian phylogenetic inference under mixed models. Bioinformatics 19: 1572-1574. https://doi.org/10.1093/bioinformatics/btg180

Sanders KL, Malhotra A, Thorpe RS (2004) Ecological diversification in a group of Indomalayan pitvipers (Trimeresurus): convergence in taxonomically important traits has implications for species identification. Journal of Evolutionary Biology 17: 721-731. https://doi. org/10.1111/j.1420-9101.2004.00735.x

Sanders KL, Malhotra A, Thorpe RS (2006) Combining molecular, morphological and ecological data to infer species boundaries in a cryptic tropical pitviper. Biological Journal of the Linnean Society 87: 343-364. https://doi.org/10.1111/j.1095-8312.2006.00568.x
Sharma SK, Pandey DP, Shah KB, Tillack F, Chappuis F, Thapa CL, Alirol E, Kuch U (2013) Venomous snakes of Nepal. Lalitpur, 75 pp. Silvestro D, Michalak I (2012) RaxmlGUI: a graphical front-end for RAxML. Organisms Diversity \& Evolution 12: 335-337. https:// doi.org/10.1007/s13127-011-0056-0

Smith MA (1943) Fauna of British India, Ceylon and Burma, including the whole of the Indo-Chinese sub-region. Reptilia and Amphibia (Vol. 3). Serpentes. Taylor and Francis, London, 583 pp.

Thompson J, Gibson T (2002) Multiple sequence alignment using ClustalW and ClustalX. Current Protocols in Bioinformatics 00(1): 2.3.1-2.3.22. https://doi.org/10.1002/0471250953.bi0203s00

Wallach V, Williams K, Boundy J (2014) Snakes of the world: a catalogue of living and extinct species. Taylor \& Francis Group, London, 1257 pp. https://doi.org/10.1201/b16901

Whitaker R, Captain A (2004) Snakes of India. The Field Guide. Draco Books, Chennai, 481 pp.

Zhong G, Zhu F, Yan F, Fu X, Fang M, Tang T, Xiao R, Wang P, Guo P, Liu Q (2015) Cryptic diversity of green pitvipers in Yunnan, southwest China (Squamata, Viperidae). Amphibia Reptilia 36: 265-276. https://doi.org/10.1163/15685381-00003004

Zhu F, Liu Q, Che J, Zhang L, Chen X, Yan F, Murphy R, Guo C, Guo P (2016) Molecular phylogeography of white-lipped tree viper (Trimeresurus; Viperidae). Zoologica Scripta 45: 252-262. https://doi. org/10.1111/zsc. 12156

\section{Appendix I}

Genbank accession numbers for sequences used in the current study.

\begin{tabular}{|c|c|c|}
\hline Name & $16 \mathrm{~S}$ & ND4 \\
\hline Trimeresurus albolabris & KF311102 & AY352837 \\
\hline Trimeresurus andersonii & AY352740 & AY352835 \\
\hline Trimeresurus borneensis & AY352722 & AY352817 \\
\hline Trimeresurus cantori & AF057243 & AY352836 \\
\hline Trimeresurus cardamomensis & KR021137 & KR021070 \\
\hline Trimeresurus erythrurus & AF517174 & AY352834 \\
\hline Trimeresurus fasciatus & GQ428466 & GQ428482 \\
\hline Trimeresurus flavomaculatus & AY059551 & AY059584 \\
\hline Trimeresurus gracilis & AY352728 & AY352823 \\
\hline Trimeresurus gramineus & AY352731 & AY352827 \\
\hline Trimeresurus gumprechti & AY352736 & AY352832 \\
\hline Trimeresurus hageni & AY059552 & AY059585 \\
\hline Trimeresurus insularis & AF517172 & AY059586 \\
\hline Trimeresurus kanburiensis & AY352737 & - \\
\hline Trimeresurus macrops & AF517176 & AF517219 \\
\hline Trimeresurus malabaricus & AY059564 & AY059587 \\
\hline Trimeresurus malcolmi & AY371793 & AY371861 \\
\hline Trimeresurus mcgregori & AY371795 & - \\
\hline Trimeresurus medoensis & AY352735 & AY352831 \\
\hline Trimeresurus popeiorum & AY059554 & AY059590 \\
\hline Trimeresurus puniceus & AF517177 & AF517220 \\
\hline Trimeresurus purpureomaculatus & AY352745 & AY352840 \\
\hline Trimeresurus rubeus & KR021141 & KR021075 \\
\hline Trimeresurus salazar BNHS 3554 & MN684366 & NA \\
\hline Trimeresurus salazar BNHS 3555 & MN684365 & MN686204 \\
\hline Trimeresurus schultzei & AY352725 & AY352819 \\
\hline Trimeresurus septentrionalis & AY352724 & AY352818 \\
\hline Trimeresurus sichuanensis & HQ850446 & HQ850450 \\
\hline Trimeresurus stejnegeri & FJ752492 & AY059595 \\
\hline Trimeresurus sumatranus & AY371788 & AY371866 \\
\hline Trimeresurus tibetanus & AY352715 & AY352810 \\
\hline Trimeresurus trigonocephalus & KC347374 & AY059597 \\
\hline Trimeresurus truongsonensis & EU443818 & EU443816 \\
\hline Trimeresurus venustus & AY352723 & AY289228 \\
\hline Trimeresurus vogeli & AF517183 & AF517225 \\
\hline Trimeresurus yunnanensis & EU443812 & EF597527 \\
\hline
\end{tabular}




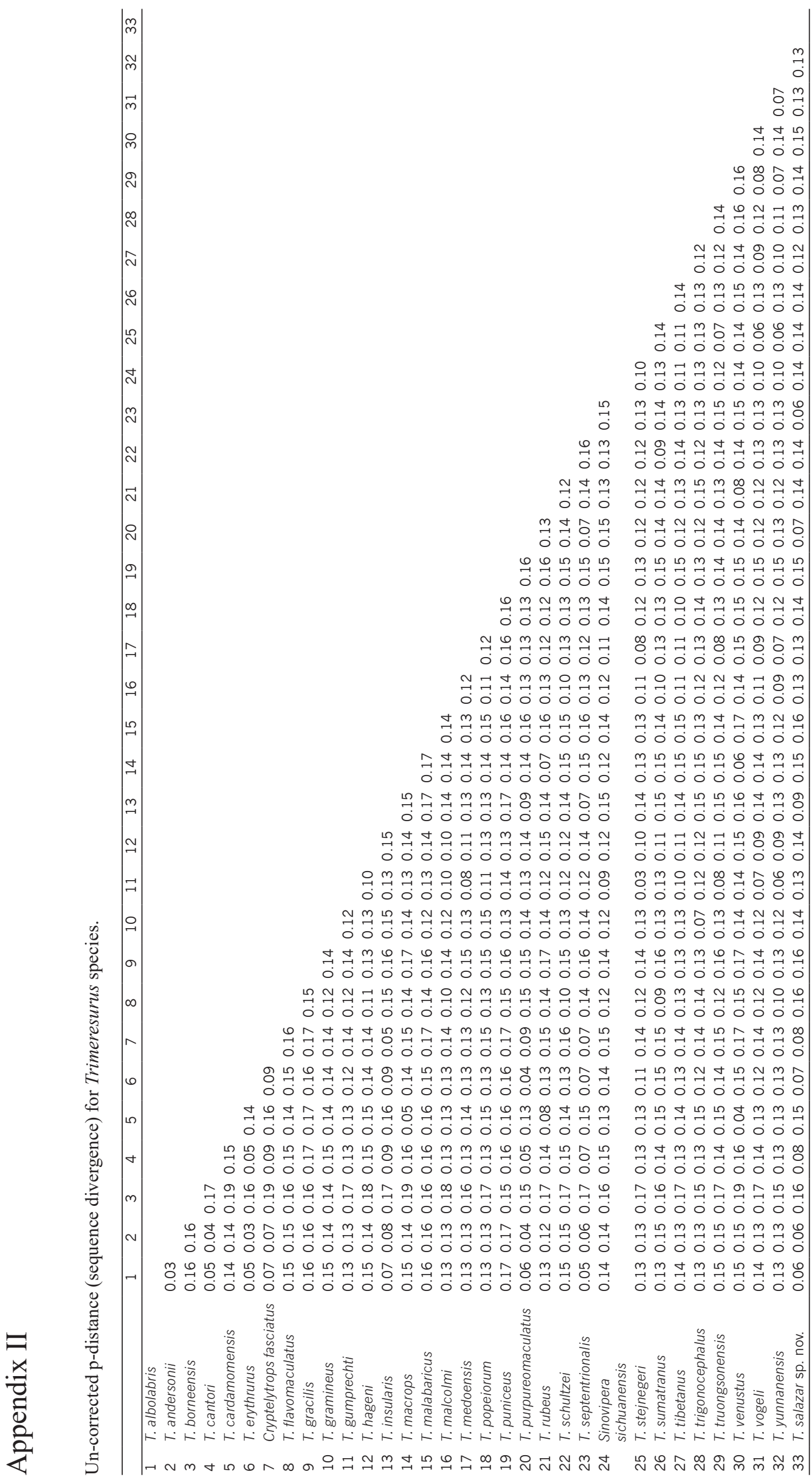




\section{Appendix III}

ML phylogeny of Trimeresurus based on partial sequences of mitochondrial 16S rRNA and ND4 gene generated through 1000 non-parametric bootstrap pseudoreplicates under the GTR + G model of sequence evolution. Numbers at nodes represent ML bootstrap support.Appendix IV

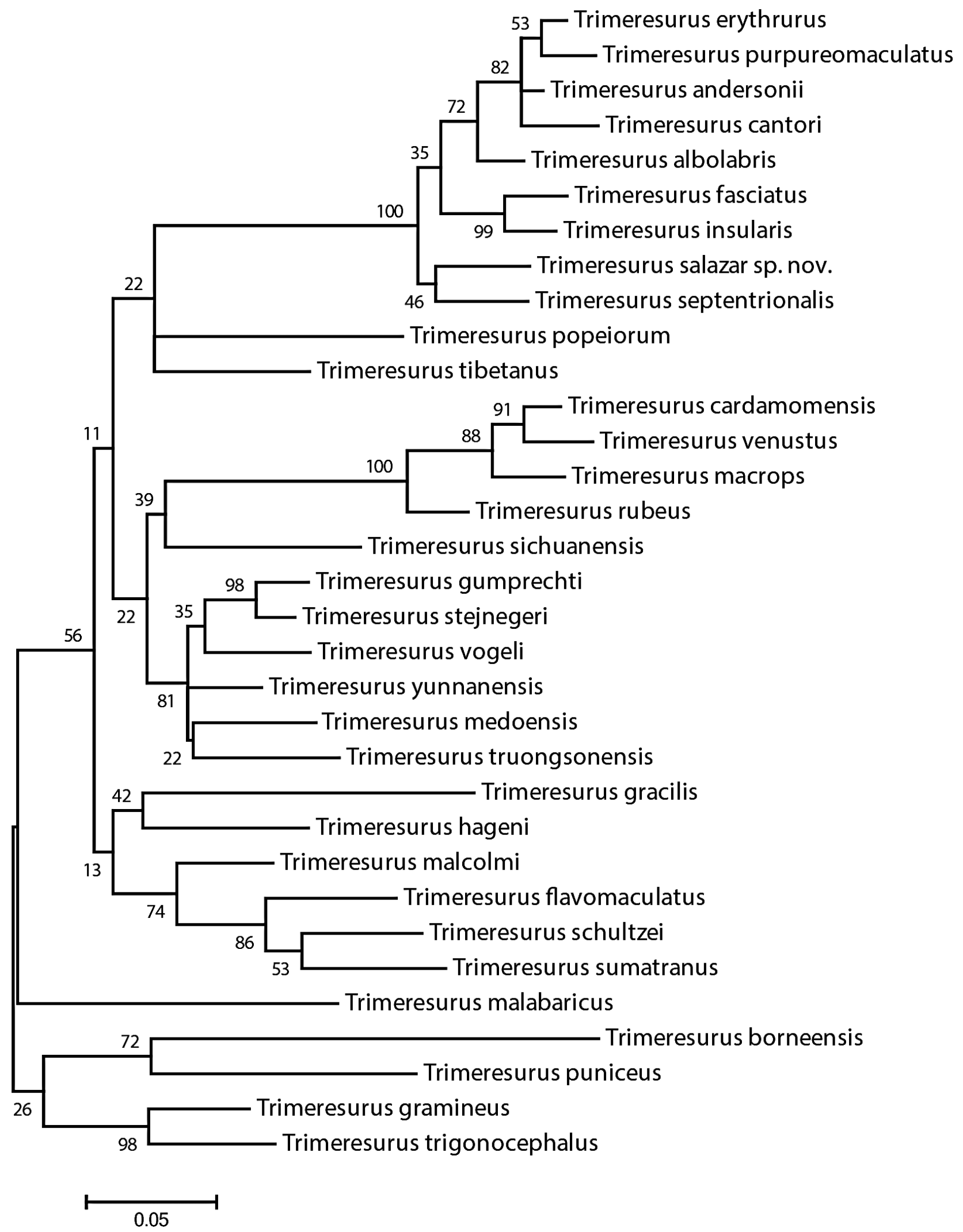


Images of female paratype of $T$. salazar sp. nov.
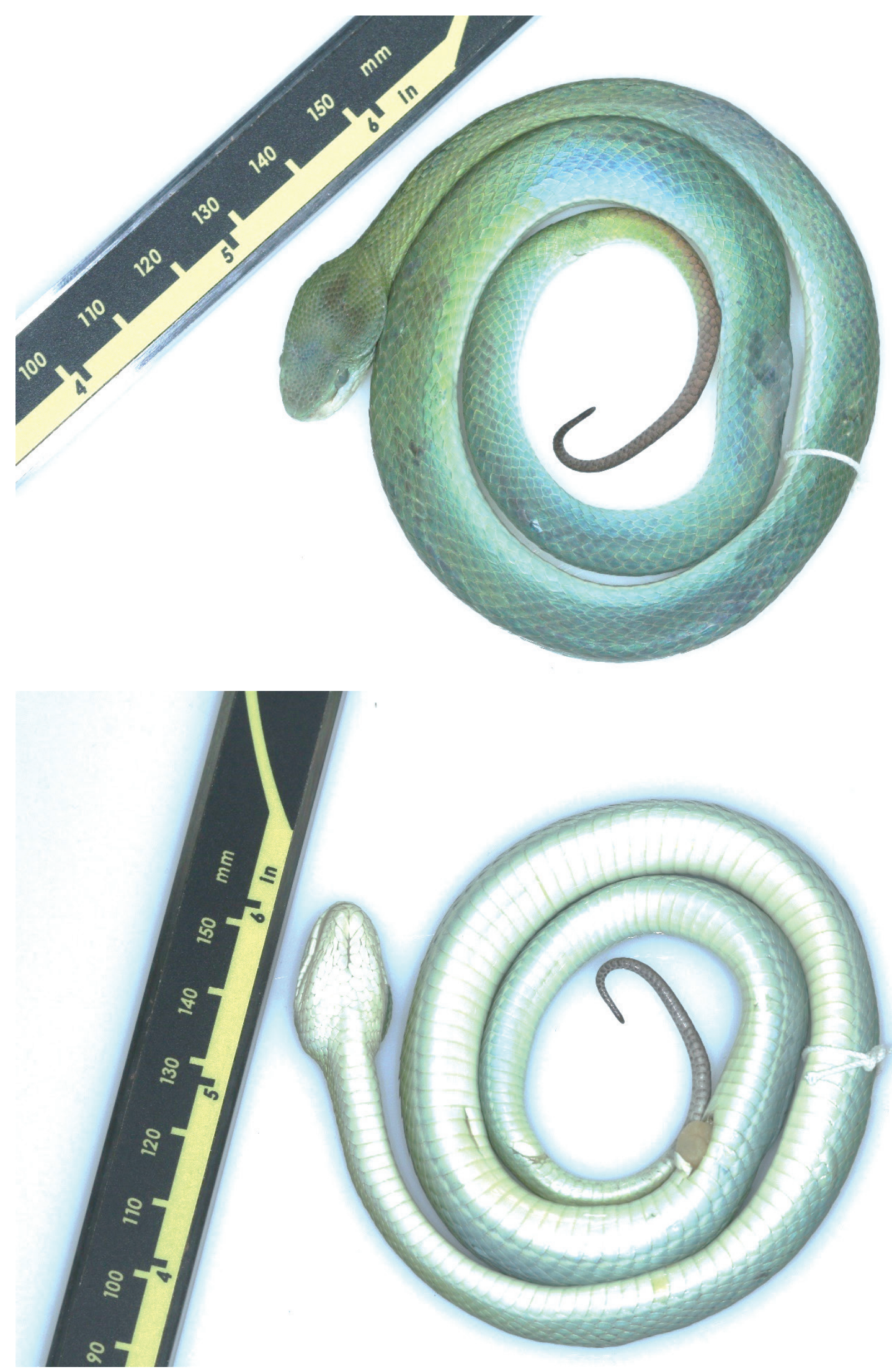

I 


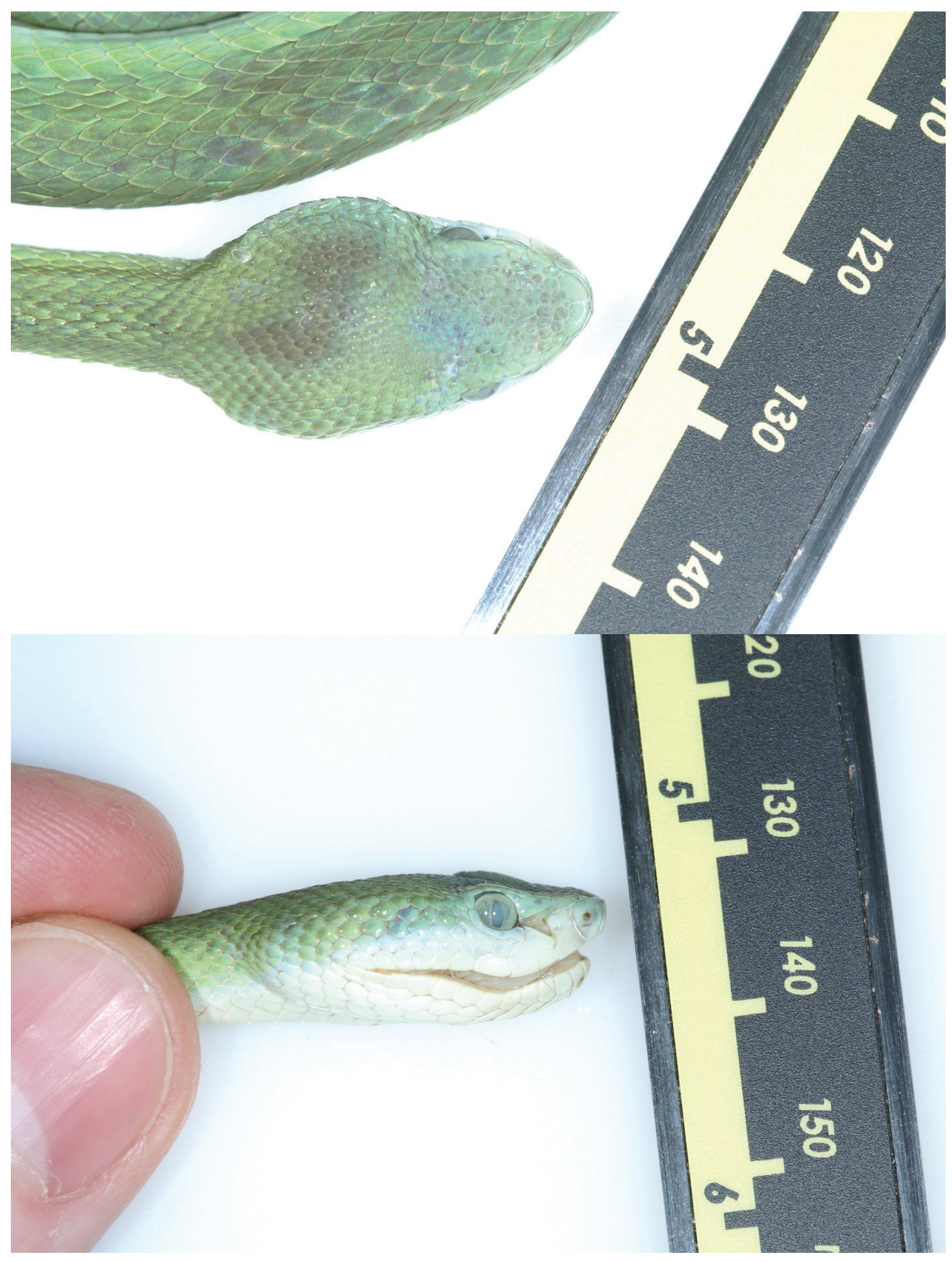




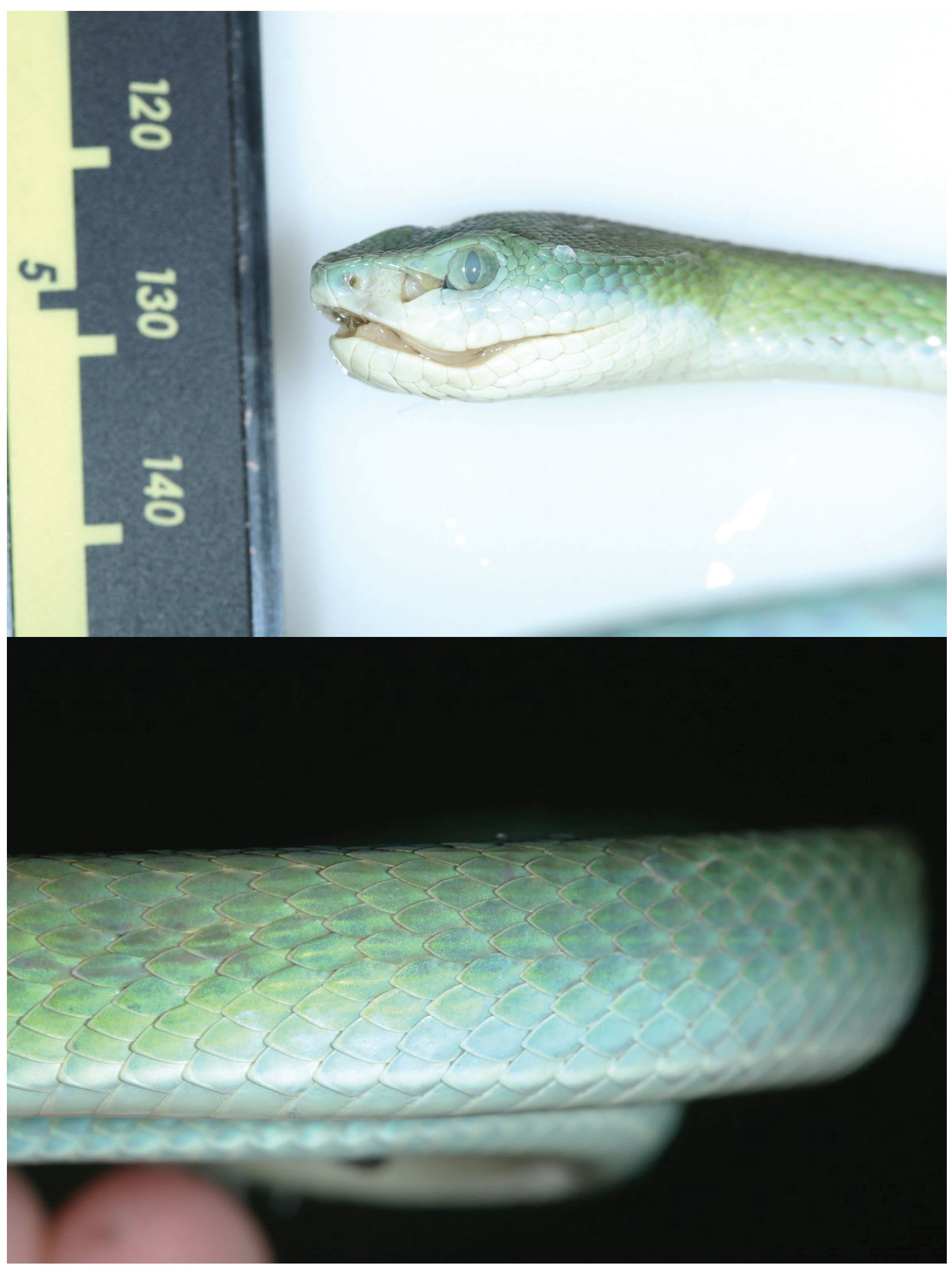

